\title{
Comparative study of survivor and nonsurvivor sepsis patients in a university hospital
}

\author{
Estudo comparativo de pacientes sobreviventes e não sobreviventes \\ com sepse em um hospital universitário
}

\author{
Aline Pâmela Vieira de Oliveira', Cristina Hueb Barata ${ }^{2}$, Eddie Fernando Candido Murta ${ }^{3}$ \\ and Beatriz Martins Tavares-Murta ${ }^{1}$
}

\begin{abstract}
To determine parameters associated with the evolution of sepsis, a five-year retrospective study was conducted in a university hospital. One hundred and four consecutive sepsis patients were evaluated, of whom $55.8 \%$ were men. The mortality was $68.3 \%$ and was associated with older age ( $<<0.05$ ). Chronic comorbidities and infection site were not associated with prognosis. Gram-positive bacteria were more frequently identified in survivors $(\mathrm{p}<0.05)$, while non-detection of the germ was associated with mortality $(\mathrm{p}<0.01)$. Appropriate use of antibiotics (germ sensitive to at least one drug administered) was associated with survival $(\mathrm{p}<0.0001)$ while inappropriate use $(\mathrm{p}<0.05)$ or empirical use $(\mathrm{p}<0.01)$ were more frequent in nonsurvivors. Leukocytosis was the main abnormality (54.8\%) detected on diagnosis, from the leukocyte count. During the evolution, normal leukocyte count was associated with survival $(\mathrm{p}<0.01)$ and leukocytosis with mortality $(\mathrm{p}<0.05)$. In conclusion, mortality was associated with nondetection of the pathogen, leukocytosis during the evolution of the sepsis and inappropriate or empirical use of antimicrobials. Evidence-based treatment that is directed towards modifiable risk factors might improve the prognosis for sepsis patients.
\end{abstract}

Key-words: Sepsis. Prognosis. Antimicrobials. Risk factors.

\section{RESUMO}

Para determinar parâmetros associados à evolução da sepse, foi realizado estudo retrospectivo de 5 anos em um hospital universitário. Foram avaliados 104 pacientes consecutivos com sepse, sendo 55,8\% homens. A mortalidade foi de 68,3\%, associada à idade elevada ( $<<0,05)$. Doenças crônicas associadas e sítio de infecção não relacionados ao prognóstico. Identificação de bactérias Gram-positivos foi mais frequente em sobreviventes $(\mathrm{p}<0,05)$ e não detecção do germe foi associada à mortalidade $(\mathrm{p}<0,01)$. 0 uso apropriado de antibióticos (germe sensível a pelo menos uma droga administrada) foi associado à sobrevida $(\mathrm{p}<0,0001)$ enquanto uso inapropriado $(\mathrm{p}<0,05)$ ou empírico $(\mathrm{p}<0,01)$ foi mais freqüiente em não sobreviventes. No diagnóstico, leucocitose foi a principal (54,8\%) alteração no leucograma. Na evolução, leucograma normal foi associado à sobrevida $(\mathrm{p}<0,01)$ e leucocitose à mortalidade $(\mathrm{p}<0,05)$. Em conclusão, a mortalidade foi associada à ausência de detecção do germe, leucocitose na evolução da sepse e uso inapropriado ou empírico de antibióticos. 0 tratamento baseado em evidências e direcionado para fatores de risco que podem ser modificados deve melhorar o prognóstico do paciente com sepse.

Palavras-chaves: Sepse. Prognóstico. Antimicrobianos. Fatores de risco.

Sepsis is a major challenge in medicine. It is a complex clinical syndrome resulting from a damaging host response to infection ${ }^{7}$. In the United States, over 700,000 patients per year develop sepsis with an unsatisfactorily high mortality rate, which is reported to range from 30 to $70 \%$, despite the best available therapeutic interventions and supportive care ${ }^{21}$.

Sepsis represents a substantial high-cost healthcare burden ${ }^{1}$ and there is limited epidemiological information about the demography of sepsis or about the temporal changes in its incidence and outcome. The occurrence of sepsis in the United States from 1979 to 2000 using a nationally representative sample showed that the incidence and number of sepsis-related deaths increased, despite a decline in the overall in-hospital mortality among sepsis patients ${ }^{17}$. Sepsis is especially common among the elderly: mortality due to sepsis increases with age, from $10 \%$ among children to $38.4 \%$ among those over 85 years old. It is likely to increase substantially as the population ages ${ }^{2}$.

\footnotetext{
1. Discipline of Pharmacology, Department of Biological Sciences, Federal University of Triângulo Mineiro, Uberaba, MG. 2. Discipline of Infectious Diseases, Department of Medical Clinics, Federal University of Triângulo Mineiro, Uberaba, MG. 3. Discipline of Gynecology and Obstetrics, Federal University of Triângulo Mineiro, Uberaba, MG. Research support by FAPEMIG (Fundação de Amparo à Pesquisa do Estado de Minas Gerais).

Address to: Prof ${ }^{a}$ Beatriz Martins Tavares Murta. Department of Biological Sciences/UFTM. Praça Manoel Terra 330, 38015-050, Uberaba, MG.

Tel: $55343318-5467$

e-mail: bmurtafarmaco@dcb.uftm.edu.br

Recebido para publicação em: 12/03/07

Aceito em: 15/01/2008
} 
Neutrophils constitute the first line in the host defense against microorganisms, and they are recruited to inflammatory sites by chemoattractants, particularly chemokines ${ }^{19}$. Once migrated, these leukocytes are able to display phagocytic activity and to generate large amounts of reactive oxygen and nitrogen species, such as hydrogen peroxide and nitric oxide, which are crucial products for the microbicidal activity of these cells ${ }^{16}$. It has been demonstrated that neutrophil migration in sepsis patients is significantly lower in nonsurvivors than in survivors, in comparison with control volunteers $^{24}$. Since neutrophils appear to play a crucial role in controlling the infectious process, it can be hypothesized that neutropenia might aggravate infections and sepsis.

Many studies have analyzed risk factors for mortality among sepsis patients. However, great variability can be noted, considering the heterogeneity of patients, geographic location and hospital type $\mathrm{e}^{3}$. In the present study, we aimed to recognize the profile of sepsis patients in our university hospital and to specifically determine factors that might influence the occurrence of prognosis disparities. We sought to examine these relationships with respect to age, gender, skin color, chronic comorbid conditions, white blood cell count, source of infection, causal organisms and use of antibiotics.

\section{PATIENTS AND METHODS}

Patients. This retrospective study enrolled 104 consecutive patients who developed sepsis in the tertiary teaching hospital of the Federal University of Triângulo Mineiro, southeastern Brazil, during a five-year period from January 2001 to November 2005. The patients who were enrolled presented clinical and/or laboratory variables that fulfilled the criteria for sepsis at its different stages of severity'. The study was approved by the Human Subjects Institutional Committee of the Federal University of Triângulo Mineiro.

Measurements. For each patient, general and specific characteristics concerning the infection and its management were collected from the medical records. These included age, gender, skin color, source of infection, causal organisms, chronic comorbid conditions and use of antimicrobials. In addition, white blood cell count was determined at two time points: upon diagnosis and within the clinical course of the sepsis, at a time close to the patient's recovery or death. In accordance with these characteristics, the patients were further analyzed in two groups: survivors and nonsurvivors.

Evaluation of use of antimicrobials. For the purposes of this investigation, the use of antimicrobials was evaluated according to the use of drugs to which documented pathogens were sensitive, as assessed by an antibiogram. Antimicrobial treatment was considered appropriate when the germ was sensitive to at least one drug used and inappropriate antimicrobial treatment included those in which none of the antibiotics used was germ-sensitive as well as drugs that were not tested by an antibiogram. Empirical use of antibiotics was considered to consist of treatment without identifying any pathogen.
Data analysis. The data were analyzed using the Prism 3 and GraphPad InStat software. Categorical variables were compared using the chi-square test. Median ages were compared using the Mann-Whitney test. The significance level was established at $p<0.05$ (two-tailed).

\section{RESULTS}

One hundred and four sepsis patients, of mean age \pm SD of $51.5 \pm 17.8$ years (range: $21-91$ ), were enrolled in this study. There were $58(55.8 \%)$ men and $46(44.2 \%)$ women, and $70(67.3 \%)$ were white and $34(32.7 \%)$ were nonwhite. In all cases, the patients developed sepsis at the hospital and the median length (and range) of hospital stay was four days (0-64) in the intensive care unit and 19 days (0-128) in noncritical care units, starting from the day of sepsis diagnosis. The overall mortality was $68.3 \%$, consisting of 35 men $(60.3 \%$ of the male population) and 36 women ( $78.3 \%$ of the female population) $(\mathrm{p}=0.082$, chi-square test). The age (median; range) was greater for nonsurvivors $(54 ; 22-91$ years) than for survivors ( $42 ; 21-81$ years) $(\mathrm{p}<0.01$, Mann-Whitney test). The mortality rate was similar for white $(68.6 \%)$ and nonwhite $(67.6 \%)$ patients.

The patients were distributed according to their chronic comorbid conditions (Table 1). Considering all the sepsis patients, $44(42.3 \%)$ had AIDS, diabetes or cancer and $29(27.9 \%)$ presented other chronic diseases (Chagas disease, pulmonary obstructive disease or renal failure), while in $31(29.8 \%)$ cases no comorbidities were reported. No statistical differences in chronic conditions were detected according to gender (data not shown). Table 1 shows the distribution of survivors and nonsurvivors according to comorbidities, without differences between the groups.

Table 1 - Distribution of chronic comorbid conditions reported among survivor and nonsurvivor sepsis patients.

\begin{tabular}{|c|c|c|c|c|c|c|c|}
\hline & \multicolumn{2}{|c|}{ Sepsis patients } & \multicolumn{2}{|c|}{ Survivors } & \multicolumn{2}{|c|}{ Nonsurvivors } & \multirow[t]{2}{*}{$p$ value } \\
\hline & $\mathrm{n}^{\underline{0}}$ & $\%$ & $\mathrm{n}^{0}$ & $\%$ & $\mathrm{n}^{\underline{0}}$ & $\%$ & \\
\hline AIDS & 16 & 15.4 & 6 & 18.2 & 10 & 14.0 & 0.80 \\
\hline Cancer & 12 & 11.5 & 4 & 12.1 & 8 & 11.3 & 0.89 \\
\hline Diabetes mellitus & 16 & 15.4 & 5 & 15.1 & 11 & 15.5 & 0.96 \\
\hline Others & 29 & 27.9 & 8 & 24.3 & 21 & 29.6 & 0.94 \\
\hline None & 31 & 29.8 & 10 & 30.3 & 21 & 29.6 & 0.74 \\
\hline Total & 104 & 100.0 & 33 & 100.0 & 71 & 100.0 & \\
\hline
\end{tabular}

The most (36.5\%) frequent source of infection was respiratory, either alone $(n=16,15.4 \%)$ or in association with other infectious sites $(n=22,21.1 \%)$, followed by genitourinary sites $(7.7 \%)$. In $44(42.3 \%)$ patients, the source of infection was considered to have an unknown origin (Table 2). Sepsis patients in whom the infection site was in the respiratory tract presented $76.3 \%$ mortality and, considering gender, $87.5 \%$ of such women died compared with $68.2 \%$ men $(p=0.25$, chi-square test). Table 2 shows that survivors and nonsurvivors did not significantly differ in relation to the source of infection, although respiratory foci reached greater frequency among nonsurvivors than among survivors. 
Table 2 - Distribution of source of infection identified among survivor and nonsurvivor sepsis patients.

\begin{tabular}{|c|c|c|c|c|c|c|c|}
\hline & \multicolumn{2}{|c|}{ Sepsis patients } & \multicolumn{2}{|c|}{ Survivors } & \multicolumn{2}{|c|}{ Nonsurvivors } & \multirow[t]{2}{*}{$p$ value } \\
\hline & $\mathrm{n}^{0}$ & $\%$ & $\mathrm{n}^{0}$ & $\%$ & $\mathrm{n}^{0}$ & $\%$ & \\
\hline Respiratory & 38 & 36.5 & 9 & 27.3 & 29 & 40.9 & 0.26 \\
\hline Genitourinary & 8 & 7.7 & 2 & 6.1 & 6 & 8.5 & 0.98 \\
\hline Skin & 5 & 4.8 & 2 & 6.1 & 3 & 4.2 & 0.68 \\
\hline Abdominal & 4 & 3.9 & 1 & 3.0 & 3 & 4.2 & 0.77 \\
\hline Others & 5 & 4.8 & 1 & 3.0 & 4 & 5.6 & 0.93 \\
\hline Nonidentified & 44 & 42.3 & 18 & 54.5 & 26 & 36.6 & 0.13 \\
\hline Total & 104 & 100.0 & 33 & 100.0 & 71 & 100.0 & \\
\hline
\end{tabular}

Microorganisms were recovered from blood cultures from $76(73.1 \%)$ patients but in $28(26.9 \%)$ cases, no pathogen was detected. Table 3 shows that there was a similar frequency of gram-positive organisms and polymicrobial sepsis, while gramnegative organisms corresponded to lesser cases. In one case, fungi were detected associated with Gram-positive pathogens. The two groups differed in relation to causative organisms. Grampositive pathogens were significantly more often recovered from survivor patients, while in the nonsurvivor group, the causative microorganism was more frequently not detected (Table 3).

Table 3 - Comparative distribution of the most common pathogens detected in the blood of survivor and nonsurvivor sepsis patients.

\begin{tabular}{|c|c|c|c|c|c|c|c|}
\hline & \multicolumn{2}{|c|}{ Sepsis patients } & \multicolumn{2}{|c|}{ Survivors } & \multicolumn{2}{|c|}{ Nonsurvivors } & \multirow[t]{2}{*}{$p$ value } \\
\hline & $\mathrm{n}^{\underline{0}}$ & $\%$ & $\mathrm{n}^{\mathrm{O}}$ & $\%$ & $\mathrm{n}^{0}$ & $\%$ & \\
\hline Gram-positive & 32 & 29.8 & 16 & 48.5 & 16 & 22.5 & $0.014 *$ \\
\hline Gram-negative & 16 & 15.4 & 4 & 12.1 & 12 & 16.9 & 0.73 \\
\hline Polymicrobial & 28 & 26.9 & 11 & 33.3 & 17 & 24.0 & 0.44 \\
\hline Non-detected & 28 & 26.9 & 2 & 6.1 & 26 & 36.6 & $0.002 *$ \\
\hline Total & 104 & 100.0 & 33 & 100.0 & 71 & 100.0 & \\
\hline
\end{tabular}

* Differences calculated by comparing survivors and nonsurvivors (chi-square test).

Concerning the use of antimicrobials, $26.9 \%$ of the patients were treated empirically. Among patients with documented infection, appropriate antibiotic use was observed in $60.6 \%$ cases, including 24 (23\%) patients in whom the germ was sensitive to all the antibiotics used. Inappropriate use was observed in relation to $13(12.5 \%)$ patients. The data in Table 4 show that antibiotic use was highly associated with prognosis. Appropriate use of antimicrobials was associated with survival $(p<0.0001)$, while inappropriate or empirical treatment was more frequent among nonsurvivor patients $(p<0.05$ and $p<0.01$, respectively) (chi-square test).

White blood cell counts were analyzed at two time points: upon diagnosis and at a time close to the patient's recovery or death. Around one third of the patients presented normal leukocyte counts, and leukocytosis was the main abnormality detected (Table 5). Although abnormalities (leukopenia or leukocytosis) did not differ between survivors and nonsurvivors upon diagnosis, they were more frequent in the nonsurvivor group when analyzed at a time point during the evolution. Statistical significance was detected for leukocytosis, while a normal white blood cell count was significantly associated with survival (Table 5).
Table 4 - Distribution of sepsis patients who received or did not receive appropriate antibiotic treatment, in relation to prognosis.

\begin{tabular}{|c|c|c|c|c|c|c|c|}
\hline & \multicolumn{2}{|c|}{ Sepsis patients } & \multicolumn{2}{|c|}{ Survivors } & \multicolumn{2}{|c|}{ Nonsurvivors } & \multirow[t]{2}{*}{$p$ value } \\
\hline & $\mathrm{n}^{0}$ & $\%$ & $\mathrm{n}^{0}$ & $\%$ & $\mathrm{n}^{0}$ & $\%$ & \\
\hline Appropriate & 63 & 60.6 & 30 & 90.9 & 33 & 46.5 & $<0.0001^{*}$ \\
\hline Not appropriate & 13 & 12.5 & 1 & 3.0 & 12 & 16.9 & $0.04 *$ \\
\hline Empirical & 28 & 26.9 & 2 & 6.1 & 26 & 36.6 & $0.0024 *$ \\
\hline Total & 104 & 100.0 & 33 & 100.0 & 71 & 100.0 & \\
\hline
\end{tabular}

* Differences calculated by comparing survivors and nonsurvivors (chi-square test).

Table 5 - Comparison between normal and abnormal white blood cell counts according to time of measurement (upon diagnosis and after evolution), among survivor and nonsurvivor sepsis patients.

\begin{tabular}{|c|c|c|c|c|c|c|c|}
\hline & \multicolumn{2}{|c|}{ Sepsis patients } & \multicolumn{2}{|c|}{ Survivors } & \multicolumn{2}{|c|}{ Nonsurvivors } & \multirow[t]{2}{*}{$p$ value } \\
\hline & $\mathrm{n}^{\underline{0}}$ & $\%$ & $\mathrm{n}^{\underline{0}}$ & $\%$ & $\mathrm{n}^{0}$ & $\%$ & \\
\hline \multicolumn{8}{|l|}{ WBC count time 1} \\
\hline normal & 37 & 35.6 & 13 & 39.4 & 24 & 33.8 & 0.73 \\
\hline leukocytosis ${ }^{\mathrm{a}}$ & 57 & 54.8 & 18 & 54.5 & 39 & 54.9 & 0.97 \\
\hline leukopenia ${ }^{\mathrm{b}}$ & 10 & 9.6 & 2 & 6.1 & 8 & 11.3 & 0.63 \\
\hline Total & 104 & 100.0 & 33 & 100.0 & 71 & 100.0 & \\
\hline \multicolumn{8}{|l|}{ WBC count time 2} \\
\hline normal & 45 & 43.3 & 21 & 63.6 & 24 & 33.8 & $0.008^{*}$ \\
\hline leukocytosis & 46 & 44.2 & 9 & 27.3 & 37 & 52.1 & $0.03^{*}$ \\
\hline leukopenia & 13 & 12.5 & 3 & 9.1 & 10 & 14.1 & 0.69 \\
\hline Total & 104 & 100.0 & 33 & 100.0 & 71 & 100.0 & \\
\hline
\end{tabular}

WBC count time 1: white blood cell count performed upon diagnosis, WBC count time 2: white blood cell count performed during clinical course of sepsis, close to the time of the patient's recovery or death.

a: WBC count $>12,000$ cells $/ \mathrm{mm}^{3},{ }^{\text {b: }}$ WBC count $<4,000$ cells $/ \mathrm{mm}^{3}$.

*Differences calculated by comparing survivors and nonsurvivors (chi-square test).

\section{DISCUSSION}

Sepsis patients are a heterogeneous group of patients with great variability in underlying illnesses, infection sites and etiological agents. This highlights the importance of identifying clinical and laboratory variables among sepsis patients that may be useful in predicting outcomes.

In this retrospective five-year study, we found 104 patients with the criteria for a diagnosis of sepsis. It is possible that this number represents underreporting, since physicians caring for sepsis patients recognize the difficulty of defining and diagnosing sepsis and are aware that they often misdiagnose such patients ${ }^{20}$.

Previous reports on high mortality among sepsis patients are also valid in relation to our hospital. Hospital mortality due to sepsis has ranged from $25 \%$ to $80 \%$ over the last few decades ${ }^{3}$. The median length of stay in the intensive care unit was similar to that reported for a Swedish university hospital ${ }^{15}$ and shorter than in previous data ${ }^{2}$. Furthermore, the median hospital stay was similar to findings from larger epidemiological studies ${ }^{2}$. The mean length of hospital stay has been decreasing and the rate of discharge to nonacute medical care facilities has been increasing ${ }^{17}$. A number of patients were treated outside the critical care unit, in part because of the reduced number of available beds and in part because of the criteria for sepsis severity. Since critical care units maintain the best supportive care, we could not rule out that this might have contributed towards mortality. 
Our study population was constituted mainly by white persons and men. The occurrence of sepsis in the United States from 1979 to 2000 was more common among men and nonwhite persons ${ }^{17}$. These individuals are considered to be at increased risk of sepsis ${ }^{12}{ }^{17}$ while others have explain the lower mortality among women in terms of differences in age, comorbidity and infection site $^{2}$. We found a higher frequency of mortality among women, which could be partially explained by the association with respiratory site. Other studies have found increased mortality among women, associated with hospitalacquired pneumonia ${ }^{9}$.

We found that around $42 \%$ of the patients had AIDS, diabetes or cancer, which was in agreement with other studies ${ }^{2}$, but the presence of chronic diseases was not associated with mortality. These underlying disorders may alter the overall immune response, even though the coagulation and inflammatory response to infection is not altered ${ }^{11}$. Clinical trials on antisepsis agents often exclude the very elderly, HIV-positive individuals and patients with malignancies because they are at higher risk of death and less likely to respond to treatment. Nonetheless, a large cohort study evaluating 192,980 patients with severe sepsis found that such patients constituted a large proportion of the sepsis population and that their exclusion would compromise the external validity of the study ${ }^{2}$.

The respiratory tract, followed by genitourinary sources, was the most frequent infection site, which was in agreement with larger epidemiological studies ${ }^{23}$. In line with our findings, other studies have found a great frequency of unspecified sites $^{2}$. We observed a mortality rate of more than $70 \%$ among patients with respiratory foci as the source of infection, and this is considered to be an independent factor associated with mortality ${ }^{810}$, whereas urosepsis is rarely fatal ${ }^{8}$.

The infection site and nature of the organism are considered to have a significant impact on survival from sepsis ${ }^{8}$. In our study, Gram-positive organisms or polymicrobial sepsis were mainly observed, and Gram-positive pathogens were associated with survival. A large retrospective study found that Gram-positive bacteria have become the predominant pathogen since 1987, and that these are an increasingly common cause of sepsis ${ }^{17}$. Gramnegative bacilli were mainly responsible for bloodstream infections in cancer patients ${ }^{26}$, and were associated with a mortality rate higher than for infection with Gram-positive organisms8.

The use of antibiotics with specific activity against identified pathogens was associated with survival, but inappropriate or empirical antimicrobial treatment was associated with greater hospital mortality. These findings serve to alert clinicians towards prioritizing blood cultures and identifying causal organisms. A recent study has encouraged modification of prescribing habits such as reductions in prescribing broad-spectrum antibacterial drugs $^{22}$. Our findings agree with others in that antimicrobial regimens that lack activity against identified microorganisms are associated with mortality among sepsis patients ${ }^{1314}$.

One hypothesis has postulated that sepsis moves through different phases, such that enhanced inflammation alternates with immunosuppression. Considering that the criteria for sepsis include high or low white blood cell counts and that this could indicate hyperinflammation or immunosuppression respectively, we sought to determine whether such alterations could be predictive for the prognosis. It was noted that at least one third of the patients had normal white blood cell counts on diagnosis. Leukocytosis and leukopenia detected during the evolution were more frequent in nonsurvivors: leukocytosis was associated with mortality and normal white blood cell counts were associated with survival. A recent study using mice that were subjected to sepsis by means of cecal ligature and puncture showed that animals that died during the evolution of the disease could present evidence of either immunosuppression or immunostimulation ${ }^{27}$.

The role of neutrophils in the development of multiple organ failure due to sepsis has been recently reviewed ${ }^{6}$. Perhaps what is of greater pathophysiological importance in causing severe sepsis is not the number of circulating neutrophils, but that these cells are not functionally active ${ }^{25}$. We have reported that blood neutrophils obtained from sepsis patients failed to respond in vitro to chemotactic stimuli and that this unresponsiveness was associated with death ${ }^{24}$. The mechanism involved was found to result from signal receptor desensitization mediated by continuous and excessive chemotactic receptor activation ${ }^{4}$. Moreover, it was found among breast cancer patients who underwent chemotherapy that a reduction in neutrophil migration was evident among patients who developed episodes of infection ${ }^{18}$.

Considering recent trials with novel antisepsis therapies, it will be important to delineate the risk factors that reflect septic processes that are potentially modifiable, from those that are not $t^{2}$. We have found that nonidentified pathogens and empirical use of antibiotics were associated with worse outcome and risk factors that could be changed.

In conclusion, this study reinforces the notion that sepsis treatment should be guided by evidence-based information, in accordance with the patient population characteristics and the microbiology profile of each institution, in a process directed towards improving the outcomes for sepsis patients.

\section{REFERENCES}

1. Adrie C, Alberti C, Chaix-Couturier C, Azoulay E, Lassence A, Cohen Y, Meshaka P, Cheval C, Thuong M, Troché G, Garrouste-Orgeas M, Timsit J-F. Epidemiology and economic evaluation of severe sepsis in France: age, severity, infection site, and place of acquisition (community, hospital, or intensive care unit) as determinant of workload and cost. Journal of Critical Care 20: 46-58, 2005.

2. Angus DC, Linde-Zwirble WT, Lidicker J, Clermont G, Carcillo J, Pinsky MR Epidemiology of severe sepsis in the United States: Analysis of incidence, outcome and associated costs of care. Critical Care Medicine 29: 1303-1310, 2001.

3. Angus DC, Wax RS. Epidemiology of sepsis: An update. Critical Care Medicine 29: 109-116, 2001.

4. Arraes SM, Freitas MS, Silva SV, Paula Neto H, Alves-Filho JC, Martins MA, BasileFilho A, Tavares-Murta BM, Barja-Fidalgo C, Cunha FQ. Impaired neutrophil chemotaxis in sepsis associates with GRK expression and inhibition of actin assembly and tyrosine phosphorylation. Blood 108: 2906-2913, 2006.

5. Bone RC, Balk RA, Cerra FB, Dellinger RP, Fein AM, Knaus WA, Schein RM, Sibbald WJ. Definitions for sepsis and organ failure and guidelines for the use of innovative therapies in sepsis. Members of the American College of Chest Physicians/Society of Critical Care Medicine Consensus Conference Committee. Critical Care Medicine 20: 864-874, 1992. 
6. Brown KA, Brain SD, Pearson JD, Edgeworth JD, Lewis SM, Treacher DF. Neutrophils in development of multiple organ failure in sepsis. Lancet 368 : 157-169, 2006

7. Cohen J. The immunopathogenesis of sepsis. Nature 420: 885-891, 2002.

8. Cohen J, Cristofaro P, Carlet J, Opal S. New method of classifying infections in critically ill patients. Critical Care Medicine 32: 1510-1526, 2004.

9. Crabtree TD, Pelletier SJ, Gleason TG, Pruett TL, Sawyer RG. Gender-dependent differences in outcome after the treatment of infection in hospitalized patients. Journal of the American Medical Association 282: 2143-2148, 1999.

10. De Miguel-Yanes JM, Andueza-Lillo JA, Gonzalez-Ramallo VJ, Pastor L, Munoz J. Failure to implement evidence-based clinical guidelines for sepsis at the ED. American Journal of Emergency Medicine 24: 553-559, 2006.

11. Dhainaut JF, Claessens YE, Janes J, Nelson DR. Underlying disorders and their impact on the host response to infection. Clinical Infectious Diseases 41: 481-489, 2005

12. Esper AM, Moss M, Lewis CA, Nisbet R, Mannino DM, Martin GS. The role of infection and comorbidity: Factors that influence disparities in sepsis. Critical Care Medicine 34: 2576-2582, 2006

13. Garnacho-Montero J, Garcia-Garmendia JL, Barrero-Almodovar AF, JimenezJimenez FJ, Perez-Paredes C, Ortiz-Leyba C. Impact of adequate empiric antibiotic therapy on the outcome of patients admitted to the intensive care unit with sepsis. Critical Care Medicine 31: 2742-2751, 2003.

14. Harbarth S, Garbino J, Pugin J, Romand JA, Lew D, Pittet D. Inappropriate initial antimicrobial therapy and its effect on survival in a clinical trial of immunomodulating therapy for severe sepsis. American Journal of Medicine 115: 529-535, 2003.

15. Jacobson S, Johansson G, Winso O. Primary sepsis in a university hospital in northern Sweden: A retrospective study. Acta Anaesthesiologica Scandinavica 48: $960-967,2004$

16. Malawista SE, Montgomery RR, van Blaricom G. Evidence for reactive nitrogen intermediates in killing of staphylococci by human neutrophil cytoplasts. A new microbicidal pathway for polymorphonuclear leukocytes. Journal of Clinical Investigation 90: 631-636, 1992.

17. Martin GS, Mannino DM, Eaton S, Moss M. The epidemiology of sepsis in the United States from 1979 through 2000. The New England Journal of Medicine 348: 1546-1554, 2003.

18. Mendonça MA0, Cunha FQ, Murta EFC, Tavares-Murta BM. Failure of neutrophil chemotactic function in breast cancer patients treated with chemotherapy. Cancer Chemotherapy and Pharmacology 57: 663-670, 2006.

19. Moser B, Wolf M, Walz A, Loetscher P. Chemokines: multiple levels of leukocyte migration control. Trends in Immunology 25: 75-84, 2004.

20. Poeze M, Ramsay G, Gerlach H, Rubulotta F, Levy M. An international sepsis survey: a study of doctor's knowledge and perception about sepsis. Critical Care 8: 409-413, 2004

21. Riedemann NC, Guo R-F, Ward PA. The enigma of sepsis. Journal of Clinical Investigation 112: 460-467, 2003.

22. Sarkar P, Gould IM. Antimicrobial agents are societal drugs: how should this influence prescribing? Drugs 66: 893-901, 2006.

23. Strehlow MC, Emond SD, Shapiro NI, Pelletier AJ, Camargo Jr CA. National study of emergency department visits for sepsis. Annals of Emergency Medicine 48: 326-331, 2006.

24. Tavares-Murta BM, Zaparolli M, Ferreira RB, Silva-Vergara ML, Oliveira CHB, Murta EFC, Ferreira SH, Cunha FQ. Failure of neutrophil chemotactic function in septic patients. Critical Care Medicine 30: 1056-1061, 2002.

25. Tsuda Y, Takahashi H, Kobayashi M, Hanafusa T, Herndon DN, Suzuki F. Three differen neutrophil subsets exhibited in mice with different susceptibilities to infection by methicillin-resistant Staphylococcus aureus. Immunity 21: 215-226, 2004.

26. Velasco E, Byington R, Martins CAS, Schirmer M, Dias LMC, Gonçalves VMSC. Comparative study of clinical characteristics of neutropenic and non-neutropenic adult cancer patients with bloodstream infections. European Journal of Clinical Microbiology \& Infectious Diseases 25: 1-7, 2006.

27. Xiao H, Siddiqui J, Remick DG. Mechanisms of mortality in early and late sepsis. Infection and Immunity 74: 5227-5235, 2006. 